King, N. (2016) Sport, Terrorism, National Security, and the 'Deep State': Components of a Longitudinal Research Programme, in Harvey, A. and Kimball, R. (eds.) Sport: Identity and Community. Oxford: Inter-Disciplinary Press, pp. 51-62.

\title{
Sport, Terrorism, National Security, and the 'Deep State': Components of a Longitudinal Research Programme
}

Neil King

\begin{abstract}
This chapter represents the first step in the design of a longitudinal research programme that seeks to critically explain the changing relationship between the 'national security' arm of the state, and sport, specifically the governance of sport, participation in sport and spectating at sports events. It can be observed that both the apparatus of the state and the 'deep state' have expanded rapidly, with consequences for sport, post the events of September 11th, 2001 in the USA and the London bombings of July 7th, 2005. The 'deep state' is defined as components of the state not normally accessible to public scrutiny due to issues of 'national security'. Whilst drawing on critical sociology and political science, this chapter argues that literature pertaining to the 'deep state' could also illuminate the relationship between the state and sport in a national security context framed by the 'war on terror'. The author identifies a provisional framework for undertaking research in this domain including a number of key themes or 'lines of enquiry'.
\end{abstract}

Key Words: Sport, national security, deep state, terrorism, governance, participation, spectating. 


\section{Introduction}

This chapter represents the early stages of enquiry into the changing relationship between the 'national security' arm of the state and three components of sport, namely: the governance of sport; participation in sport; and spectating at sports events. The outcome will be a monograph provisionally entitled Sport, Terrorism, and the Deep State: A post-9/11 analysis. 1 The potential employment of the 'deep politics' literature for explaining change in global sport governance, for example, acquires particular significance given the rapid expansion of the national security apparatus of the state since 9/11.2 The research rationale centres on a defence of 'democracy' (where the accountability of the state is to the public) within a broader focus on social justice. The author perceives a growing 'democratic deficit' in this regard as the apparatus of the 'national security state' expands. The author is interested in how sport is shaped by the interests of the state-deep state nexus and how sports bodies, individual participants and spectators negotiate an environment framed by a national security discourse.

\section{Theorising Sport, Terrorism, and National Security}

In order to theorise the intersection of sport and 'national security', the author will initially draw on a broad family of theoretical frameworks and methodologies 3 including approaches within critical sociology and the sociology of sport;4 insights from geo-political analysis;5 the 'soft power' literature; 6 critical terrorism studies; 7 political violence and the Olympics;8 and policy studies.9 It is argued that an interdisciplinary or trans-disciplinary approach would result in the fullest understanding of problematic concepts and practices pertaining to 'national security', such as 'terrorism', 'the state' and 'power'. Additionally, the research programme will assimilate insights from the literature around the 'deep state'.10 The theoretical basis of the work will therefore emerge as the research is undertaken. 


\section{Sport, Terrorism, and National Security: An Overview}

Prior to $9 / 11$, there were many incidences, albeit very different in nature, where sport and 'terrorism' became intertwined, leading to state intervention and/or a response by governing bodies of sport. For example, the terrorist attack by the Black September group at the Munich Olympic Games in 1972;11 the bomb detonated by one individual with 'political motives' at the Atlanta Olympic Games in 1996; the abandoned Grand National horse racing event in Liverpool in 1997 due to a bomb threat by the Irish Republican Army (IRA); and Australia's cricket authorities withdrawal of the national team from Sri Lanka in 1996 following the bombing of a central bank and the cricket authorities refusal to tour Pakistan since 1998 due to concerns over player safety.

However, since $9 / 11$, state intervention in sport has increased, parallel to the growth of 'terrorist' networks, however defined or constructed. The list below provides brief details of some of the key events where the relationship between the state and sport has been affected. Some events are excluded as they do not directly relate to the post-9/11 context, such as the 2002 bombing of an area outside of Real Madrid football club's stadium by ETA (Basque separatists) in 2002. Instead, the events listed here relate to Islamic militancy or claims by governments that this is the case. 'Terrorist' incidents have included:

- Bomb outside of the hotel where the New Zealand cricket team were based in Karachi, Pakistan, resulting in three deaths

- attacks on the Iraq Olympic squad in 2006 including kidnappings resulting in missing athletes and twenty reported deaths

- the cancellation of the annual Dakar Rally in 2008 due to threats by Al Qaeda 
- an attack by 12 gunmen on Sri Lanka's cricket team in Lahore in 2009

- the Indian government's re-location of the IPL cricket competition from India to South

Africa following the Islamic militant attacks in Mumbai in 2008

- the Al-Shabaab bombing of a football match in Uganda in 2010

- an attack on the Togo national football team prior to the FIFA World Cup in South Africa in 2010

- the threat of 'terror' attacks resulting in the withdrawal of multiple athletes from the Commonwealth Games in India in 2010

- Islamic militias threatening television spectators of the FIFA World Cup 2014 with violence

- the Boston Marathon bombings on 'Patriot's Day' 2013 in the USA.

Responses from governments and governing bodies of sport to 'terrorism' have varied. As some incidents are sport-specific and others are not directly related to sport, and some 'events' do not involve a terrorist incident, but a threat, the research will create typologies for subsequent analysis. It is also difficult to disentangle 'terrorist' acts from state's crimes against democracy, where it is relatively unproblematic for governments to make exaggerated claims of 'thwarted terrorist plots' in order to legitimise increasing powers, which was a criticism of the Chinese authorities at the time of the 2008 Beijing Olympics. 12

\section{Literature review: Components of a Research Programme}

\section{A. The Rising Costs of Security}

Where cities are now major targets for hostile attack,13 staging mega-events such as the Olympic Games and the FIFA World Cup requires significant and escalating security budgets and counter-terrorist strategies that are now a core element of planning.14 Budgets have increased from US\$66m in 1992 (Barcelona Olympics) to US\$6.5bn in 2008 (Beijing 
Olympics).15 Omitting the Beijing games as being a unique case of 'unlimited' state support, the general trend is nonetheless upwards, doubling from Athens 2004 to almost US $\$ 2 \mathrm{bn}$ for staging the Olympics in London 2012. Also of note for analysts is the expanding private sector involvement in sport mega-events, shaping the relationship between citizens and the state. 16

B. The Extended Powers of the State

To an extent, the 'national security state' began to impact on sport pre-9/11 at the Sydney Olympic Games in the year 2000.17 Uppermost in the minds of the organisers were concerns that the event might become a terrorist target given Australia's allegiance to US military interventions. The bomb at the previous Olympics in Atlanta may also have raised security concerns. In brief, Olympic security laws were introduced, police powers extended, freedom of movement and the right to assemble curtailed, and public order offences introduced. However, of greater significance is the extended legislative lifespan of these measures where 'special purpose' laws became embedded in state law.

In respect of governing sport, it can be argued that the state has intervened legitimately to investigate corruption such as at the Salt Lake City Winter Olympics in 2002, where the US Department of Justice led the investigation. However, where civil liberties are compromised by the state, the relationship between sport and the state becomes problematic. For example, the use of surveillance technologies in public spaces 18 became a legacy of the Olympic Games. In Athens 2004, the CCTV infrastructure was retained for surveillance of the local population subsequent to the Olympic Games, and legislation introduced included the introduction of non-jury criminal trials, initiated limited right of appeal, DNA testing without consent and expanding police powers of infiltration and surveillance of groups and 
individuals.19 Moreover, the Olympics Act 2006 (sections 19 and 22) empowers police to enter private property to confiscate 'unauthorized protest materials', however defined. More recently, at the 2012 London Olympics, the constant surveillance and filming of spectators and local residents by CCTV, helicopters and drones has been observed, in addition to the closure of public thoroughfares and the increased presence of military personnel and equipment.20 It can also be noted that the games involved all 51 police forces in the UK, extensive MI5 preparations and the employment of Ministry of Defence (MOD) powers to locate missiles in high density residential areas without public consultation. From a 'deep politics' perspective, sports events have been appropriated by national security interests that in effect serve to re-define the 'social contract' between the state and citizens.

Moreover, it can be argued that these measures set a precedent for future events (sport-related or not) and this legacy represents an expansion of irreversible state power and arguably, a wider militarisation of society. This line of enquiry will be pursued as one component of the proposed research. Also of note is that state power, in the form of legislation that resulted from 'terrorist events', can be utilized at sports events. Following 9/11, and subsequently the London bombings on July 7th, 2005, the day after the Olympic bid was won by London, the UK government introduced a raft of legislation that extends police, MOD and Treasury powers. These measures may impact directly on sport in regards to protest at events, the experience of spectating and participation, and sports governance, although this area of research is currently under-explored.

C. The Extended Powers of the 'Deep State'

The extended role and reach of intelligence agencies in sport, as one component of the 'deep state', could form part of the proposed research programme. The Federal Bureau of 
Investigation (FBI) is currently investigating the Qatar 2022 World Cup bid, for example, which may have consequences for the governance of international soccer. This may in part be in recognition of soccer becoming a multimillion dollar industry with global 'ideological reach'. Also of note is the 'Greek Watergate' case 21 where it is suspected that US intelligence agencies wire-tapped members of the Greek government prior to the 2004 Olympic Games in regard to security issues. Further, it is noted that international sport has been used 'as a cover for espionage in the service of states for the purposes of military, economic and political advantage'.22 Clearly, this line of research poses significant practical and ethical challenges.

\section{The Scope for Protest, Dissent and Critique}

Civil unrest and political protest at sports events is nothing new.23 From the Tlatelolco 'massacre' of student protestors with legitimate concerns around social justice in Mexico City in 196824 at the height of the civil rights movement, to the Brazilian police and army taking control of some of the favelas in Rio de Janerio, resulting in 46 deaths, in 2014, it is clear that the state is willing to intervene forcefully on behalf of corporate interests embedded in elite sport. Arguably, within a 'national security' context, legitimate protest can be re-defined by the state as 'terrorism'. This body of literature is outside the scope of this chapter but is a rich area for further research. It can also be noted that citizen protest against the state is bound-up with the use of sport stadia for unintended purposes, such as state executions in Chile25 following the country's own 9/11 in 1973 when a democracy was overthrown in a coup d'etat supported by the Central Intelligence Agency (CIA). Researching 'sport' can therefore be a point of access for raising wider debates concerning 'democracy' and the 'deep state'. 


\section{E. The Militarisation of Society}

In the 1940s, political scientist Harold Lasswell26 warned of a 'garrison state' emerging where 'men of violence' shape the state and its objectives. It could be argued that, almost seventy years later, an emerging 'garrison state', post 9/11, is re-drawing the boundaries between the military and civilian domains. In this sense, objectives, strategies and tactics utilized in the 'deep state' have become instruments of the state. In this process, civil society (including the life-world of sport), once at arm's length from the state, becomes a soft power resource 27 for the realisation of 'deep state' objectives. From this perspective, sport megaevents are 'markers', demonstrating power, and sports governing bodies have become compliant to the will of the 'garrison state' (or 'national security state').

More broadly, in nation states where war is the 'organizing principle of society'28 and society emerges from economically sanctioned violence, the militarisation of sport is arguably inevitable. As noted, post 9/11, issues of national security have become central to sport, where the apparatus of the state and 'deep state' are now a permanent feature of sports events. More recently, disability sport too has been appropriated by the "national security state' as a soft power resource as seen in the Invictus Games in London, 2014. Promoted by the UK monarchy, and with significant media coverage, these games support those injured in war, whilst conveniently ignoring the fact that the UK monarchy and UK government are active supporters of the arms trade.29 Further, large corporate arms traders such as a BAE Systems invest in elite sport in the UK, embedding and normalizing such practices.

In terms of understanding the impact of expanding the national security apparatus on the relationship between the state and citizens, the Boston Marathon bombings is a significant event ripe for further analysis for a number of reasons: the fact that it occurred in the US; it 
took place at an event not only for elite sport, but for community participation; and it became a marker and signifier for building 'patriotism' or 'super-patriotism', where sport and patriotism have a long-standing symbiotic relationship, particularly in the USA. The impact for sports fans of Homeland security surveillance at sports events, post 9/11, could be further investigated too, and a few published studies provide a foundation on which to build this research.30 A related line of enquiry would be to investigate the extent to which sports bodies appropriate the objectives, strategies and tactics of 'deep state' operatives to meet their own objectives. For example, it has been observed that the World Anti-Doping Agency (WADA), funded in part by the US and UK governments, uses surveillance systems in tracking drug use by athletes. 31

\section{Discussion: Introducing the 'Deep State' into an Analysis of Sport}

The aim of the 'deep politics' literature is to raise public consciousness around the workings of the 'deep state' that undermine democratic forms of governance, public policy and the public interest. This approach can be aligned to critical theories in sociology that advocate emancipatory politics and embody a concern for social justice. Nonetheless, post-structuralist critique will be accounted for at the outset of this research programme given that 'deep politics' also focuses on deconstructing dominant ideologies and official histories. Peter Dale Scott32 has researched and published a series of books on US foreign policy since the 1960s, and latterly has written extensively on the 'military-corporate complex' since the catalysing event of 9/11. The 'deep politics' literature has subsequently been drawn on by UK authors such as Nafeez Ahmed.33 Scott and Ahmed investigate 'structures of power' in the statedeep state nexus in part by analysing the objectives, strategies and tactics used by 'operatives' (individuals, organisations, networks or coalitions). Operatives in the 'deep state' are found to be semi-autonomous from regulatory, legal or 'democratic' frameworks. As a 
result, operatives acquire 'diminished accountability' and impunity for their actions. This is not to suggest that the dominant interests in the 'deep state' share common objectives or act uniformly. Instead, the 'deep state' (as is the case within the state) can be viewed as the sum of a number of groups that antagonistically compete for resources, each in pursuit of its own agenda.

The 'deep politics' literature claims that 'democracy' has been 'captured' by powerful political, military and corporate interests and therefore pluralist accounts of power are perceived to be naïve. Whereas the state or 'public state' can be characterised in terms of democratic governance operating in an 'open' society with checks and balances on the use of power, the 'deep state' is characterised by unaccountable interest groups operating in secret that use deception to achieve specific objectives. Although the reach of the 'deep state' varies across nations, the 'deep state' in the UK is seen as shaping and being shaped by the decisions and actions of the state (or foreign states, notably the USA) through a narrative of 'national security'. In sum, it is argued that the 'deep politics' literature sensitizes the researcher to the complexity of the relationship between the (public) state, deep state and sport, and provides tools for analysis. However, it is acknowledged that this approach is under-theorised by comparison with approaches within critical sociology and political science, in part because of the constraints facing researchers undertaking empirical research in an area less visible to public scrutiny.

\section{Areas for further research}

This research programme will explore, analyse and seek to explain both how the "national security' discourse, and related practices, set the parameters for sport governance, participation and spectating, and how sports bodies, participants and spectators comply, 
adapt, and/or resist the reach of the 'garrison state'. Research will focus, at the outset, on how counter-terrorism measures are shaping the governance of international and domestic sport. It is anticipated that a theoretical and methodological framework will emerge as the research programme takes effect. Research components will include an analysis of: budgets and infrastructure for the security of sports events; legislation relating to 'terrorism'; citizen surveillance; state control over local populations, protest and dissent; and the wider militarisation and corporatisation of sport and society. Findings of the research are to be shared with the sport governance community with the objective of generating discussion and action to defend (community/grass-roots) sport as a 'life-world' semi-autonomous from the state/deep-state nexus and the corporate interests associated with 'national security' objectives.

\section{Notes}

1 Neil King, Sport, Terrorism, and the Deep State: A Post-9/11 Analysis, Unpublished working manuscript (forthcoming, 2016).

2 Peter Dale Scott, The Road to 9/11: Wealth, Empire and the Future of America (New York: Rowman and Littlefield, 2007); David Sylvan, 'The Garrison State from an Institutional Perspective: Was Lasswell Right?' CIS Seminar Podcast (Oxford University, 3 February 2012).

3 Richard Giulianotti and Francisco Klauser, 'Sport and “Terrorism”: A Critical Analysis', International Review for the Sociology of Sport 47. 3 (2012): 307-23.

4 Alan Bairner, Sport, Nationalism and Globalization. European and North American Perspectives (New York: State University of New York, 2001); John Sugden and Alan Tomlinson, Power Games: A Critical Sociology of Sport (London: Routledge, 2002).

5 Michael Hardt and Antonio Negri, Empire (Cambridge, Massachusetts: Harvard University Press, 2004). 6 Jonathan Grix and Barrie Houlihan, Sports Mega-Events as Part of a Nation's Soft Power Strategy: The Cases of Germany (2006) and the UK (2012), unpublished working paper. (University of Birmingham, 2012); Joseph Nye, Soft Power: The Means to Success in World Politics (New York: Public Affairs, 2004). 
7 Ruth Blackeley, State Terrorism and Neo-Liberalism. Critical Terrorism Studies (Abingdon: Routledge, 2009).

8 Anthony Richards, Peter Fussey and Andrew Silke, eds., Terrorism and the Olympics (London: Routledge, 2011).

9 Barrie Houlihan, 'Public Sector Sport Policy: Developing a Framework for Analysis', International Review for the Sociology of Sport, 40.2 (2005): 163-185.

10 Peter Dale Scott, The Road to 9/11.

11 Kay Schiller and Chris Young, The 1972 Olympics and the Making of Modern Germany (Los Angeles: University of California Press, 2010).

12 Martin Belam, Keeping the Torch Burning: Terror, Protest and the Games (London: Guardian Books, 2012).

13 Hank Savitch, 'Does 9-11 Portend a New Paradigm for Cities?' Urban Affairs Review 39. 1 (2003): $103-27$.

14 Barrie Houlihan and Richard Giulianotti, 'Politics and the London 2012 Olympics: The (In) Security

Games', International Affairs, 88. 4 (2012): 701-717.

15 Philip Boyle and Kevin Haggerty, 'Spectacular Security: Mega-Events and the Security Complex’, International Political Sociology 3.2 (2009): 257-74.

16 Keith Bradsher, 'China Finds American Allies for Security’, New York Times, 28 December 2012.

17 Helen Jefferson Lenskyj, The Best Olympics Ever? Social Impacts of Sydney 2000, (New York: State University of New York Press, 2002); Kristine Toohey and Tracey Taylor, 'Surveillance and Securitization: A Forgotten Sydney Olympic Legacy', International Review for the Sociology of Sport, 47.3 (2012): 324-337. 18 John Sugden, 'Watched by the Games, Surveillance and Security at the Olympics', in Watching the Olympics, Politics Power and Representation, eds. John Sugden and Alan Tomlinson (London, Routledge, 2011).

19 Barrie Houlihan and Richard Giulianotti, 'Politics and the London 2012 Olympics: The (In) Security Games'.

20 Richard Giulianotti and Francisco Klauser, ‘Sport and “Terrorism”: A Critical Analysis'.

21 John Sugden, 'Sport and Spies, the Dark Side of Sport and International Relations', in Image, Power and Space: Studies in Consumption and Identity, eds.

Alan Tomlinson and Jonathan Woodham (Maidenhead, UK: Meyer and Meyer, 2008).

22 Ibid., 42. 
23 Nicolien Van Luijk and Wendy Frisby, '(Re) Framing of Protest at the 2010 Winter Olympic Games', International Journal of Sport Policy and Politics, 4.3 (2012): 343-359.

24 Joe Richman and Anajansi Diaz-Cortes, ‘Mexico’s 1968 Massacre: What Really Happened?’ Radio Diaries, 1 December 2008.

25 Berhard Hachleitner, 'Das Stadium als Gefängnis', quoted in Richard Giulianotti and Francisco Klauser, 'Sport and “Terrorism”: A Critical Analysis', International Review for the Sociology of Sport 47. 3 (2012): 30723.

26 Jay Stanley, Essays on the Garrison State.

27 Jonathan Grix and Barrie Houlihan, Sports Mega-Events as Part of a Nation's Soft Power Strategy: The Cases of Germany (2006) and the UK (2012).

28 Michael Hardt and Antonio Negri, Empire.

29 Richard Norton, ‘The Future British King, Saudi Princes, and a Secret Arms Deal', The Guardian, 24 February 2014.

30 Pete Fussey and Jon Coaffee, 'Balancing Local and Global Security Leitmotivs: Counter-Terrorism and the Spectacle of Sporting Mega-Events', International Review for the Sociology of Sport, 47.3 (2012): 268-285. Also refer to Kimberly Schimmel, 'Protecting the NFL/Militarising the Homeland: Citizen Soldiers and Urban Resilience in Post-9/11 America', International Review for the Sociology of Sport, 47.3 (2012a): 338357.

31 Ivan, Waddington, 'Surveillance and Control in Sport: A Sociologist Looks at the WADA Whereabouts System', International Journal of Sport Policy and Politics, 2.3 (2010): 255-274.

32 Peter Dale Scott, The Road to 9/11: Wealth, Empire and the Future of America.

33 Nafeez Ahmed, The War on Truth. 9/11, Disinformation, and the Anatomy of Terrorism (Northampton, Massachusetts: Olive Branch Press, 2005). 


\section{References}

Ahmed, Nafeez. The War on Truth. 9/11, Disinformation, and the Anatomy of Terrorism. Northampton, Mass. USA: Olive Branch Press, 2005.

Bairner, Alan. Sport, Nationalism and Globalization. European and North American Perspectives. New York: State University of New York, 2001.

Belam, Martin. Keeping the Torch Burning: Terror, Protest and the Games. London: Guardian Books, 2012.

Blackeley, Ruth. State Terrorism and Neo-Liberalism. Critical Terrorism Studies. Abingdon: Routledge, 2009.

Boyle, Philip and Kevin Haggerty. 'Spectacular Security: Mega-Events and the Security Complex'. International Political Sociology 3.2 (2009): 257-74.

Closs Stephens, Angharad and Nick Vaughan-Williams. Terrorism and the Politics of Response. Critical Terrorism Studies. London: Routledge, 2009.

Fussey, Peter and Jon Coaffee. 'Balancing Local and Global Security Leitmotivs: CounterTerrorism and the Spectacle of Sporting Mega-Events'. International Review for the Sociology of Sport, 47.3 (2012): 268-285.

Grix, Jonathan and Barrie Houlihan. 'Sports Mega-Events as Part of a Nation's Soft Power Strategy: The Cases of Germany (2006) and the UK (2012)'. Unpublished working paper. Birmingham: University of Birmingham, 2012.

Giulianotti, Richard and Francisco Klauser. 'Sport and "Terrorism”: A Critical Analysis'. International Review for the Sociology of Sport 47.3 (2012): 307-23.

Hardt, Michael and Antonio Negri. Empire. Cambridge, Massachusetts: Harvard University Press, 2004.

Houlihan, Barrie. 'Public Sector Sport Policy: Developing a Framework for Analysis'. International Review for the Sociology of Sport, 40.2 (2005): 163-185. 
Houlihan, Barrie and Richard Giulianotti. 'Politics and the London 2012 Olympics: The (In) Security Games'. International Affairs, 88. 4 (2012): 701-717.

Jackson, Richard, Marie Breen Smyth, and Jeroen Gunning, eds. Critical Terrorism Studies: A New Research Agenda. London: Routledge, 2009.

Jackson, Richard, Eamon Murphy and Scott Poynting, eds. Contemporary State Terrorism: Theory and Practice. London: Routledge, 2010.

Lenskyj, Helen Jefferson. The Best Olympics Ever? Social Impacts of Sydney 2000. New York: State University of New York Press, 2002.

King, Neil. Sport, Terrorism, and the Deep State: A Post-9/11 Analysis. Forthcoming 2016.

Norton-Taylor, Richard. 'The Future British King, Saudi Princes, and a Secret Arms Deal'. The Guardian, 24 February 2014. Viewed 6 November 2014. http://www.theguardian.com/uk-news/defence-and-securityblog/2014/feb/24/armsgulf-prince-charles.

Nye, Joseph. Soft Power: The Means to Success in World Politics. New York: Public Affairs, 2004.

Richards, Anthony, Peter Fussey and Andrew Silke, eds. Terrorism and the Olympics. Political Violence. London: Routledge, 2011.

Savitch, Hank. 'Does 9-11 Portend a New Paradigm for Cities?' Urban Affairs Review 39. 1 (2003): 103-27.

Schiller, Kay and Chris Young. The 1972 Olympics and the Making of Modern Germany. Los Angeles: University of California Press, 2010.

Schimmel, Kimberly. 'Protecting the NFL/Militarising the Homeland: Citizen Soldiers and Urban Resilience in Post-9/11 America'. International Review for the Sociology of Sport, 47.3 (2012a): 338-357. 
Schimmel, Kimberly. 'Major Sport Events and Global Threats/Responses'. Criminal Justice Matters, 88.1 (2012b): 20-21.

Scott, Peter Dale. The Road to 9/11: Wealth, Empire and the Future of America. New York: Rowman and Littlefield, 2007.

Scott, Peter Dale. The War Conspiracy: JFK, 9/11 and the Deep Politics of War. New York: Rowman and Littlefield, 2008.

Scott, Peter Dale. American War Machine. Deep Politics, the CIA Global Drug Connection and the Road to Afghanistan. New York: Rowman and Littlefield, 2010.

Stanley, Jay, ed. Essays on the Garrison State. New Brunswick, USA: Transaction Publishers, 1997.

Sugden, John and Alan Tomlinson. Power Games: A Critical Sociology of Sport. London: Routledge, 2002.

Sugden, John. 'Sport and Spies, the Dark Side of Sport and International Relations'. In Image, Power and Space: Studies in Consumption and Identity, edited by Alan Tomlinson and Jonathan Woodham, pp 41-64. Maidenhead, UK: Meyer and Meyer, 2008.

Sugden, John. 'Watched by the Games, Surveillance and Security at the Olympics'. In Watching the Olympics, Politics Power and Representation, edited by John Sugden and Alan Tomlinson, pp 228-241. London: Routledge, 2011.

Sylvan, David. The Garrison State From an Institutional Perspective: Was Lasswell Right?. CIS Seminar, Oxford University, 3 February 2012.

Taylor, Tracey and Kristine Toohey. 'Ensuring Safety at Australian Sport Event Precincts: Creating Securitised, Sanitised and Stifling Spaces?' Urban Studies, 48.15 (2011): $3259-3275$. 
Toohey, Kristine and Tracey Taylor. 'Surveillance and Securitization: A Forgotten Sydney Olympic Legacy’. International Review for the Sociology of Sport, 47.3 (2012): 324337.

Van Luijk, Nicolien and Wendy Frisby. '(Re) Framing of Protest at the 2010 Winter Olympic Games'. International Journal of Sport Policy and Politics, 4.3 (2012): 343-359.

Waddington, Ivan. 'Surveillance and Control in Sport: A Sociologist Looks at the WADA Whereabouts System'. International Journal of Sport Policy and Politics, 2.3 (2010): 255-274. 